\title{
Effects of Silver Nanoparticles on Radish Sprouts: Root Growth Reduction and Modifications in the Nutritional Value
}

\author{
Nubia Zuverza-Mena ${ }^{1,2,3}$, Raul Armendariz², Jose R. Peralta-Videa ${ }^{2,3}$ and \\ Jorge L. Gardea-Torresdey2,3*
}

\begin{abstract}
${ }^{1}$ Metallurgical and Materials Engineering Department, The University of Texas at El Paso, El Paso, TX, USA, ${ }^{2}$ Chemistry Department, The University of Texas at EI Paso, El Paso, TX, USA, ${ }^{3}$ University of California Center for Environmental Implications of Nanotechnology - The University of Texas at EI Paso, El Paso, TX, USA
\end{abstract}

\section{OPEN ACCESS}

Edited by:

Nelson Marmiroli,

University of Parma, Italy

Reviewed by:

Jürgen Kreuzwieser,

University of Freiburg, Germany

Sibia Ranjbar,

Temple University, USA

${ }^{*}$ Correspondence:

Jorge L. Gardea-Torresdey jgardea@utep.edu

Specialty section:

This article was submitted to Functional Plant Ecology,

a section of the journal

Frontiers in Plant Science

Received: 28 August 2015 Accepted: 18 January 2016 Published: 16 February 2016

Citation: Zuverza-Mena N, Armendariz R, Peralta-Videa JR and Gardea-Torresdey JL (2016) Effects of Silver Nanoparticles on Radish Sprouts: Root Growth Reduction and Modifications in the Nutritional Value.

Front. Plant Sci. 7:90

doi: 10.3389/fpls.2016.00090
Reports indicate that silver nanoparticles (nAg) are toxic to vegetation, but little is known about their effects in crop plants. This study examines the impacts of $\mathrm{nAg}$ on the physiology and nutritional quality of radish (Raphanus sativus) sprouts. Seeds were germinated and grown for 5 days in nAg suspensions at $0,125,250$, and $500 \mathrm{mg} / \mathrm{L}$. Seed germination and seedling growth were evaluated with traditional methodologies; the uptake of $\mathrm{Ag}$ and nutrients was quantified by inductively coupled plasma-optical emission spectroscopy (ICP-OES) and changes in macromolecules were analyzed by infrared (IR) spectroscopy. None of the nAg concentrations reduced seed germination. However, the water content (\% of the total weight) was reduced by $1.62,1.65$, and $2.54 \%$ with exposure to 125,250 , and $500 \mathrm{mg} / \mathrm{L}$, respectively, compared with the control. At $500 \mathrm{mg} / \mathrm{L}$, the root and shoot lengths were reduced by 47.7 and $40 \%$, with respect to the control. The seedlings exposed to $500 \mathrm{mg} / \mathrm{L}$ had $901 \pm 150 \mathrm{mg} \mathrm{Ag} / \mathrm{kg}$ dry wt and significantly less $\mathrm{Ca}, \mathrm{Mg}, \mathrm{B}, \mathrm{Cu}, \mathrm{Mn}$, and $\mathrm{Zn}$, compared with the control. The infrared spectroscopy analysis showed changes in the bands corresponding to lipids (3000-2800 $\left.\mathrm{cm}^{-1}\right)$, proteins (1550-1530 $\left.\mathrm{cm}^{-1}\right)$, and structural components of plant cells such as lignin, pectin, and cellulose. These results suggest that nAg could significantly affect the growth, nutrient content and macromolecule conformation in radish sprouts, with unknown consequences for human health.

Keywords: silver nanoparticles, radish, FTIR, elemental analysis, macromolecules

\section{INTRODUCTION}

The "Nano-Era" started in the late 1990's propelled by the worldwide increase in government investments into nanomaterials (NMs) and their applications. In the United States, the National Nanotechnology Initiative, created at the beginning of 2000, had coordinated the research and development of nanotechnology (Roco, 2003). Since then, a number of carbon-based and metalbased NMs have been produced and are currently being used in many fields. NMs are commonly referred to as small objects with one or more external dimensions in the size range 1-100 nm. At these dimensions, materials exhibit a distinctive behavior in comparison to larger particles of the 
same composition. Silver is an important component in the area of NMs, with over 450 metric tons of silver nanoparticles (nAg) produced in 2010 (Keller et al., 2013). In November 2014, fifty percent of the nano-enabled products on the "Project on Emerging Nanotechnologies" inventory contained n $\mathrm{Ag}^{1}$. Among other goods, listed products included wound dressings with bactericidal effects that enhance healing, antibacterial door knobs and anti-odor socks; all articles containing $\mathrm{nAg}$ that provide antimicrobial properties (Kim et al., 2007). At some point, it is assumed that all the nanoparticles (NPs) in different items will end up in the soil, air or water (Keller et al., 2013). Even though some studies have reported the effects of $\mathrm{nAg}$ in the environment (Daniel et al., 2010; Beer et al., 2012), their toxicity on crop plants is not yet well understood. Previous investigations indicate that the effects of $\mathrm{nAg}$ on seed germination vary with NP characteristics and plant species. Kumari et al. (2009) reported that $\mathrm{nAg}$ decrease the mitotic index and cause multiple chromosomal breaks and cell disintegration in onion (Allium cepa). Stampoulis et al. (2009) found that $\mathrm{nAg}$ at 500 and $100 \mathrm{mg} / \mathrm{L}$ reduced plant biomass and transpiration in zucchini (Cucurbita pepo) by 57 and 41\%, respectively. In another experiment, C. pepo sp. ovifera was exposed in hydroponics to 0, 100, and $500 \mathrm{mg} \mathrm{nAg/L} \mathrm{and} \mathrm{corresponding} \mathrm{bulk} \mathrm{Ag} \mathrm{(Ag}$ powder). Results showed more negative effects in plants exposed to nAg than bulk Ag (Musante and White, 2012). It has also been observed that $\mathrm{nAg}$ reduced growth in mung bean (Phaseolus radiatus) and sorghum (Sorghum bicolor) cultivated in soil or agar-based medium (Lee et al., 2012). In addition, Pokhrel and Dubey (2013) found that coated nAg promoted histological changes in maize (Zea mays L.) by inducing elongation of root cells, and reduced root growth in cabbage (Brassica oleracea var. capitata L.) by $24 \%$. In tomato (Solanum lycopersicum), nAg did not affect germination even at $5000 \mathrm{mg} / \mathrm{L}$ (Song et al., 2013). Thuesombat et al. (2014) reported that the toxicity of $\mathrm{nAg}$ in rice (Oryza sativa cv. KDML 105) increased directly with the particle size and concentration. A more recent report indicates that $\mathrm{nAg}$ at a concentration of $100 \mathrm{mg} / \mathrm{L}$ reduced germination in Brassica nigra (Amooaghaie et al., 2015). However, the effects of $\mathrm{nAg}$ on radish have not been reported yet. Radish (Raphanus sativus L.) sprouts are widely consumed worldwide due to their nutritional content and antioxidant properties (Xiao et al., 2014; Baenas et al., 2015). More than two decades ago, radish was proposed as a model plant for the study of environmental stresses, mainly atmospheric contaminants (Kostka-Rick and Manning, 1993). More recently, due to its short growing period, this plant has been considered as a model of edible roots for the study of the interaction of plants with soil contaminants (Létondor et al., 2015). A few reports have shown different responses of radish seedlings exposed to NMs. Ma et al. (2010) reported that $\mathrm{nLa}_{2} \mathrm{O}_{3}, \mathrm{nGd}_{2} \mathrm{O}_{3}$, and $\mathrm{nYb}_{2} \mathrm{O}_{3}$ at $2000 \mathrm{mg} / \mathrm{L}$ inhibited root elongation. However, Trujillo-Reyes et al. (2013) found that citric acid coated $\mathrm{nCeO}_{2}$, at $200 \mathrm{mg} / \mathrm{L}$, increased root biomass and seedlings' water content. In addition, Corral-Diaz et al. (2014) reported that $\mathrm{nCeO}_{2}$ at $250 \mathrm{mg} / \mathrm{kg}$ soil increased radish tubers' antioxidant capacity. There is concern about

${ }^{1}$ http://www.nanotechproject.org/cpi/ the trophic transfer of NPs from edible plants into the food chain (Gardea-Torresdey et al., 2014). The present investigation addresses the effects of a nAg suspension, intended for human ingestion, in a terrestrial plant. In this study, radish seeds were exposed to different $\mathrm{nAg}$ concentrations from a commercially available $\mathrm{nAg}$ suspension to test its effects on radish sprouts. The marketed nAg product, at $500 \mathrm{mg} / \mathrm{L}$ per serving, is indicated as a dietary supplement for immune support ${ }^{2}$. Even though the environmental concentrations of $\mathrm{nAg}$ are lower than the amounts used for this study (Gottschalk et al., 2013), we chose $500 \mathrm{mg} / \mathrm{L}$ as the highest concentration for the experiment, assuming the worst case scenario for this product. The effects on seedlings' development, nutrient uptake and changes of macromolecules were studied by using spectrophotometric analytical techniques.

\section{MATERIALS AND METHODS}

\section{Silver Nanoparticles and Radish Seeds}

Silver nanoparticles (nAg) from Natural Path/Silver Wings (Nashville, TN, USA) came suspended in deionized water at $500 \mathrm{mg} / \mathrm{L}$. According to the manufacturer, the majority of the $\mathrm{nAg}$ are $2 \mathrm{~nm}$ in size forming colloids in the range of 1-10 $\mathrm{nm}$. The hydrodynamic size of the suspended particles in water and the zeta potential $(\zeta$, the electrostatic charge between particles) was analyzed by dynamic light scattering (DLS) using a Malvern Zetasizer (Nano-ZS90, Malvern Instruments, UK). Radish (Champion variety) seeds were obtained from Del Norte Seeds and Feed (Vinton, TX, USA).

\section{Seed Germination}

Thirty seeds were directly incubated without previous treatment in sterilized standard Petri dishes $(10 \mathrm{~cm}$ diameter $)$ over germination paper, modified from López-Moreno et al. (2010). Treatments consisted of $\mathrm{nAg}$ suspensions at 0 (control), 125, 250, and $500 \mathrm{mg} / \mathrm{L}$; four replicates per treatment. The concentrations for the study were selected considering that the worst case scenario at which plants could be exposed is the commercially available product of $\mathrm{nAg}$ at $500 \mathrm{mg} / \mathrm{L}$. Suspensions were prepared by diluting the stock suspension of $500 \mathrm{mg} / \mathrm{L}$ (as supplied by the vendor) with Millipore water $(18 \mathrm{M} \Omega \mathrm{cm})$. We utilized Millipore water for the experiments because it has similar resistivity than deionized water (Yin et al., 2012). Aliquots of five milliliters of $\mathrm{nAg}$ suspension were administered to each Petri dish, except for control seeds that received five milliliters of Millipore water. The dishes containing the seeds were covered with aluminum foil for 3 days. Then, they were set into a growth chamber (Environmental Growth Chamber, Chagrin Falls, OH, USA), where seedlings grew for a total of 5 days before analysis. Environmental conditions inside the chamber were $25 / 20^{\circ} \mathrm{C}$ day/night temperature, $14 / 10 \mathrm{~h}$ light/dark photoperiod, $60 \pm 3 \%$ relative humidity, and $340 \mu \mathrm{mol} / \mathrm{m}^{2} \mathrm{~s}$ light intensity. The

${ }^{2}$ http://www.npswsilver.com/ 
percent germination $(\% \mathrm{G})$, relative germination ( $\% \mathrm{RG})$, and germination change (\%GC) were calculated as per de la Rosa et al. (2011). The length of the roots and shoots was measured on 15 plants per replicate. Water content, fresh and dry weights (dry wt) were also determined on 15 plants per replicate.

\section{Elemental Analysis}

At harvest, seedlings were washed with $0.01 \mathrm{M} \mathrm{HNO}_{3}$ and rinsed with Millipore water to remove the $\mathrm{nAg}$ adhered to tissues. After washing, seedlings were oven dried at $70^{\circ} \mathrm{C}$ for $72 \mathrm{~h}$ (Corral-Diaz et al., 2014). Dried samples were prepared for analysis, according to the EPA method 3051. Briefly, the seedlings were powdered using mortar and pestle and acid digested (0.1 g per sample) with a 1:4 ratio of $\mathrm{HNO}_{3}: \mathrm{H}_{2} \mathrm{O}_{2}$ in a microwave oven (MarsX, CEM Mathews, NC, USA). Digested samples were placed in $15 \mathrm{~mL}$ polypropylene centrifuge tubes and the final volume was adjusted to $15 \mathrm{~mL}$. The digests were analyzed for macronutrients, micronutrients, and Ag content by using inductively coupled plasma-optical emission spectroscopy (ICP-OES, Perkin Elmer Optima 4300 DV, Shelton, CT, USA). For quality assurance/quality control, a standard of $0.5 \mathrm{mg} / \mathrm{L}$ from the calibration curve that contained Ag, micro and macro elements was analyzed every five samples.

\section{FT-IR Analysis}

Changes in lipids, proteins, carbohydrates and other organic polymers (e.g., lignin) were studied by using Fourier transform infrared (FT-IR) spectroscopy. The sprouts were washed with $0.01 \mathrm{M} \mathrm{HNO}_{3}$ and rinsed with Millipore water, separated into roots, stems and leaves and oven dried at $70^{\circ} \mathrm{C}$ for at least $72 \mathrm{~h}$. Samples of roots, stems, and leaves were analyzed by using a Perkin-Elmer, Spectrum 100 with a Universal Attenuated Total Reflectance (ATR) sampling accessory. Background correction was performed by acquiring a spectrum without sample. Powdered samples were placed on the spectrometer stand and spectra were recorded. The data was collected in a frequency range from 4000 to $600 \mathrm{~cm}^{-1}$ at a resolution of $1 \mathrm{~cm}^{-1}$ and three scans per reading. Results are averages of triplicate determinations, as similarly reported by Servin et al. (2013). The amide I peak is commonly taken as an internal standard to normalize biological samples' spectra (Yu and Irudayaraj, 2005). Data was normalized at wavenumber $1650 \mathrm{~cm}^{-1}$ for roots, stems, and leaves. This allowed us to compare the spectra within the same plant tissue at different $\mathrm{nAg}$ concentrations.

\section{Statistical Analysis}

Data was analyzed using the Statistical Package for the Social Sciences 20.0 (SPSS, Chicago, IL, USA). Variance was evaluated by one-way analysis of variance (one-way ANOVA) and the difference between treatment means was compared by Tukey's honest significant difference (Tukey's HSD) test at a p-value of 0.05 , unless otherwise stated. Regression analysis was performed on growth data.

\section{RESULTS}

\section{Characterization and Effects of nAg on Seed Germination}

The $\mathrm{nAg}$ suspended in Millipore water had (at the highest concentration) a hydrodynamic size of $77 \pm 2.44 \mathrm{~nm}$ and a zeta potential $(\zeta)$ of $-24.4 \pm 12.6 \mathrm{mV}$. Results suggest that $\mathrm{nAg}$ may be aggregating given that the manufacturer specifications indicate a colloid size of 1-10 nm. Note that our recorded dimensions $(77 \pm 2.44 \mathrm{~nm})$ include any layer that forms around the $\mathrm{nAg}$ due to interactions with the aqueous media, where the inorganic complex is suspended (Supplementary Figure S1).

Supplementary Figure S2 shows an overall view of the experimental setup, while Supplementary Figure S3 shows enlarged views of one Petri dish/treatment. The germination percent and changes in germination of radish seeds exposed to $\mathrm{nAg}$ are shown in Table 1 . As seen in this table, at $125 \mathrm{mg} / \mathrm{L} \mathrm{nAg}$ increased the germination by $3 \%$, while at 250 and $500 \mathrm{mg} / \mathrm{L}$ reduced the germination by 3 and $6 \%$, respectively. However, none of the treatments reached a statistical significant difference in comparison to the control.

\section{Seedling Growth, Silver Uptake, Biomass Production, and Water Content}

Figure 1 shows the root and shoot elongation, dry biomass production, water content, and $\mathrm{Ag}$ concentration in seedlings exposed to $\mathrm{nAg}$ at 0 (control), 125, 250, and $500 \mathrm{mg} / \mathrm{L}$. Individual images of seedlings from the different treatments are shown in Supplementary Figure S4. As seen in Figure 1A, accumulation of $\mathrm{Ag}$ was concentration dependent, but there was no difference between 125 and $250 \mathrm{mg} / \mathrm{L}$ treatments (114 and $204 \mathrm{mg} \mathrm{Ag} / \mathrm{kg}$ dry tissue, respectively). However, at $500 \mathrm{mg} / \mathrm{L}, \mathrm{Ag}$ accumulation was significantly higher (900 mg Ag/kg dry tissue) compared to the other treatments $(p \leq 0.05)$.

The elongation of roots and shoots is shown in Figure 1B. As shown in this figure, there was a concentration-dependent reduction in root elongation $\left(r^{2}=0.9626\right)$ that reached statistical significance in seedlings exposed to 250 and $500 \mathrm{mg} / \mathrm{L}$ with respect to control. The percent reductions in the two treatments were 27.3 and $47.7 \%$, respectively. In addition, the root length of seedlings exposed to $500 \mathrm{mg} / \mathrm{L}(5.2 \mathrm{~cm})$ was statistically lower compared to the length of roots exposed

\begin{tabular}{|c|c|c|c|c|}
\hline & (Control) 0 mg/L & 125 mg/L & $250 \mathrm{mg} / \mathrm{L}$ & $500 \mathrm{mg} / \mathrm{L}$ \\
\hline$\% G$ & $93 \pm 1$ & $96 \pm 3$ & $90 \pm 4$ & $88 \pm 1$ \\
\hline$\% R G$ & $100 \pm 1$ & $103 \pm 3$ & $97 \pm 4$ & $94 \pm 1$ \\
\hline$\% \mathrm{GC}$ & $0 \pm 1$ & $3 \pm 3$ & $-3 \pm 4$ & $-6 \pm 1$ \\
\hline
\end{tabular}

Results are means of four replicates \pm standard error. 

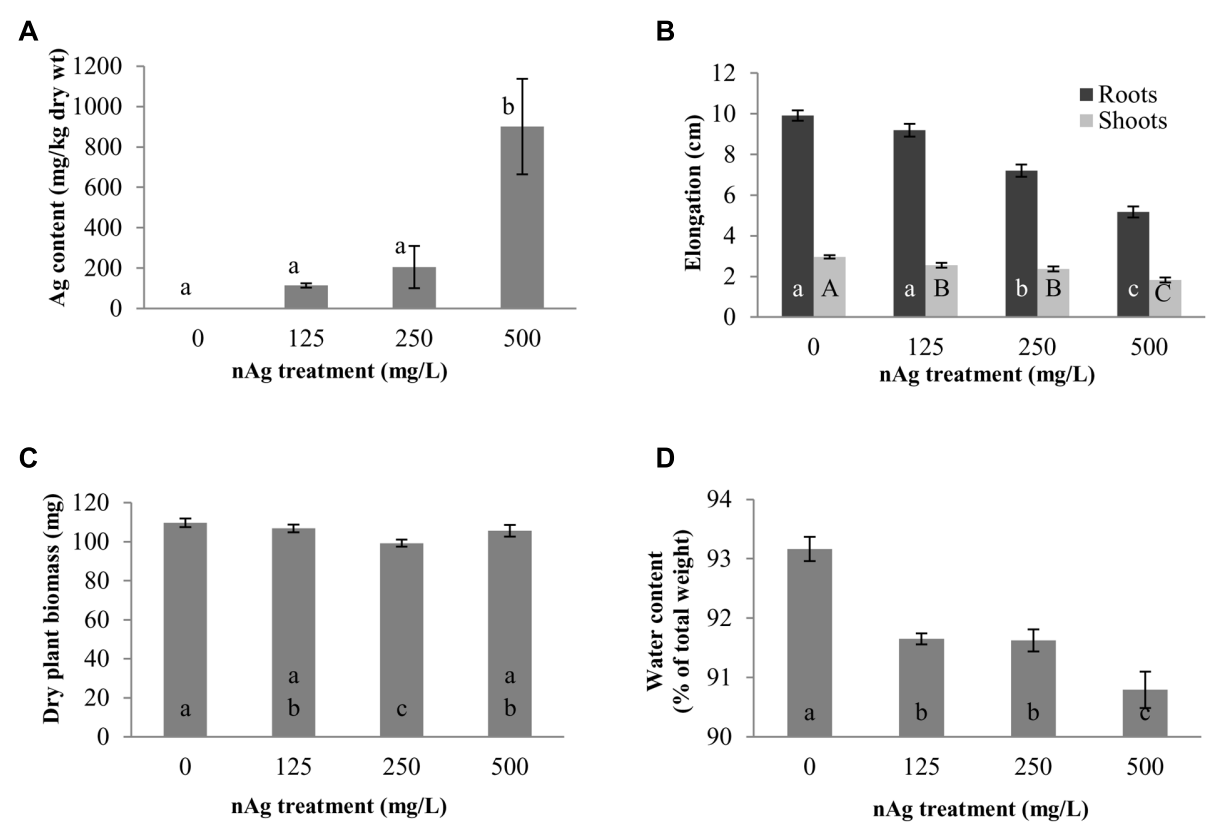

FIGURE 1 | Concentration of Ag, mg per kg of dry plant tissue (A), root and shoot length (B), dry biomass (C), and water content (D) in radish seedlings exposed for $\mathbf{5}$ days to $\mathrm{nAg}$ at $\mathbf{0}$ (control), 125, 250, and $\mathbf{5 0 0} \mathbf{~ m g / L}$. Values are means of four replicates per treatment (15 plants each replicate) \pm standard error. Different letters denote statistically significant differences according to the Tukey's HSD test $(p<0.05)$. In (B), small case letters are for roots and upper case letters for shoots.

to $250 \mathrm{mg} / \mathrm{L}(7.2 \mathrm{~cm})$. Figure $1 \mathbf{B}$ also shows the shoot length of radish seedlings. Similar to root length, there was a concentration-dependent significant reduction $\left(r^{2}=0.9677\right)$ in shoot elongation. However, in the case of shoots, all $\mathrm{nAg}$ concentrations significantly reduced shoot elongation, although the reduction at 125 and $250 \mathrm{mg} / \mathrm{L}$ was statistically similar. At $500 \mathrm{mg} / \mathrm{L} \mathrm{nAg}$ exposure, the reduction in shoot length reached $38 \%$.

The effects of nAg on dry biomass are shown in Figure 1C. Plants exposed to $250 \mathrm{mg} / \mathrm{L}$ had less biomass, compared with control and the other treatments. The reduction was about $10 \%$, compared with control, and about $7 \%$ compared with the other treatments.

Water content of the whole seedlings is shown in Figure 1D. As shown in this figure, the water content (expressed as \% of the total seedlings' weight) was reduced by $1.62,1.65$, and $2.54 \%$ with exposure to 125,250 , and $500 \mathrm{mg} / \mathrm{L}$, respectively, compared with the control. In all cases the differences were statistically significant, compared with the control; however, there were no differences between the 125 and $250 \mathrm{mg} / \mathrm{L}$ treatments $(p \leq 0.05)$.

\section{Effects of $n A g$ on Macro and Micronutrient Accumulation}

Figure 2 shows the concentration of elements that were affected by $\mathrm{nAg}$ in the whole seedling. Amongst macroelements, only $\mathrm{Ca}$ and $\mathrm{Mg}$ were significantly reduced by the highest concentrations of nAg (Figure 2A). Calcium was reduced by 20 and 33\% and $\mathrm{Mg}$ by 10 and $19 \%$ at 250 and $500 \mathrm{mg} / \mathrm{L}$, respectively, compared with control.
With regard to micronutrient absorption, none of the $\mathrm{nAg}$ concentrations impaired the absorption of $\mathrm{Fe}, \mathrm{Ni}$, and Mo. However, all treatments significantly reduced $(p \leq 0.05)$ absorption of $\mathrm{B}, \mathrm{Mn}$, and $\mathrm{Cu}$, while $\mathrm{Zn}$ was only reduced at $500 \mathrm{mg} / \mathrm{L}$, compared with control (Figure 2B). Percent reductions at 125,250 , and $500 \mathrm{mg} / \mathrm{L}$ were $32,36.8$, and $44.6 \%$ for $\mathrm{B} ; 11.6,14.8$, and $26.9 \%$ for $\mathrm{Mn}$, and $47.5,52.5$, and $52.5 \%$ for $\mathrm{Cu}$, respectively. Zinc was reduced by $12.6 \%$ at the highest concentration treatment.

\section{FT-IR Analysis of Roots, Stems, and Leaves}

Fourier transform infrared spectroscopy has been used to identify conformational changes in the macromolecules of plants exposed to contaminants, including NPs. Table 2 provides a summary of previously compiled FT-IR data from plant samples that relates the functional groups identified and the macromolecules involved (Dokken and Davis, 2007; Lammers et al., 2009; Rico et al., 2015). For comparison purposes, we chose specific spectral regions where lipids $\left(3000-2800 \mathrm{~cm}^{-1}\right)$, proteins and lignin $\left(1700-1500 \mathrm{~cm}^{-1}\right)$, lipids and pectin $(1790-$ $\left.1720 \mathrm{~cm}^{-1}\right)$ cellulose, and hemicellulose $\left(1300-1180 \mathrm{~cm}^{-1}\right)$ and other carbohydrates (fingerprint region 1200-900 $\mathrm{cm}^{-1}$ ) are presumably found. Changes in the FT-IR spectra of radish seedlings (Figures 3-5) were compared with the data shown in Table 2. There are no apparent band shifts in the FT-IR spectra of the roots, stems or leaves treated with nAg at different concentrations as seen in Figures 3-5. However, changes in band intensities were found in all studied regions. 
TABLE 2 | Summary of FT-IR band frequencies found in plants exposed to NPs and other contaminants (Dokken and Davis, 2007; Lammers et al., 2009; Rico et al., 2015).

\begin{tabular}{|c|c|c|c|c|}
\hline Frequency $\left(\mathrm{cm}^{-1}\right)$ & Literature freq. $\left(\mathrm{cm}^{-1}\right)$ & Functional group & Molecule/tissue component & From \\
\hline \multirow[t]{6}{*}{$3100-2800$} & $3100-3000$ & $\mathrm{C}-\mathrm{H}$ aromatic & - & Lammers et al., 2009 \\
\hline & $3000-2800$ & C-H aliphatic & - & Lammers et al., 2009 \\
\hline & 2960-2940 & $\mathrm{CH}_{3}$ asymmetric & Lipids & Dokken and Davis, 2007 \\
\hline & 2930-2910 & $\mathrm{CH}_{2}$ asymmetric & Lipids & Dokken and Davis, 2007 \\
\hline & $2885-2860$ & $\mathrm{CH}_{3}$ symmetric & Lipids & Dokken and Davis, 2007 \\
\hline & 2860-2840 & $\mathrm{CH}_{2}$ symmetric & Lipids & Dokken and Davis, 2007 \\
\hline \multirow[t]{4}{*}{$1790-1720$} & $1790-1744$ & $\mathrm{C}=\mathrm{O}$ & Carboxyl ester, lipids, esterified pectins & Rico et al., 2015 \\
\hline & 1749 & $\mathrm{COOH}$ & Carboxylate $\mathrm{COOH}$, pectin & Lammers et al., 2009 \\
\hline & 1742,1732 & $\mathrm{C}=\mathrm{O}$ & Ester carbonyls, polysaccharides & Lammers et al., 2009 \\
\hline & 1740 & $\mathrm{C}=\mathrm{O}($ alkyl) & Lipids, esterified pectins & Dokken and Davis, 2007 \\
\hline \multirow[t]{7}{*}{$1700-1500$} & $1664-1648$ & $\mathrm{C}=\mathrm{O}, \mathrm{C}-\mathrm{N}$ & Protein & Rico et al., 2015 \\
\hline & 1650 & $\mathrm{C}=\mathrm{O}, \mathrm{C}-\mathrm{N}$ & Protein & Dokken and Davis, 2007 \\
\hline & 1635 & Aromatic $\mathrm{C}=\mathrm{C}$ & Lignin & Dokken and Davis, 2007 \\
\hline & 1632 & Aromatic $\mathrm{C}=\mathrm{C}$ & Lignin & Rico et al., 2015 \\
\hline & $1630-1605$ & $\mathrm{COOH}$ & Carboxylate $\mathrm{COOH}$, pectin & Lammers et al., 2009 \\
\hline & $1568-1536$ & $\mathrm{~N}-\mathrm{H}, \mathrm{C}-\mathrm{N}$ & Protein & Rico et al., 2015 \\
\hline & 1550 & $\mathrm{~N}-\mathrm{H}, \mathrm{C}-\mathrm{N}$ & Protein & Dokken and Davis, 2007 \\
\hline \multirow[t]{2}{*}{$1300-1180$} & $1250-1240$ & Asymmetric $\mathrm{C}-\mathrm{O}-\mathrm{H}$ & Cellulose, hemicellulose & Dokken and Davis, 2007 \\
\hline & $1248-1216$ & Asymmetric $\mathrm{C}-\mathrm{O}-\mathrm{H}$ & Cellulose, hemicellulose & Rico et al., 2015 \\
\hline \multirow[t]{7}{*}{ 1200-900 } & 1200-900 & - & Carbohydrate & Dokken and Davis, 2007 \\
\hline & $1150-1060$ & $\mathrm{C}-\mathrm{O}-\mathrm{C}$ (ether) & Lignin & Lammers et al., 2009 \\
\hline & 1150-980 & $\mathrm{C}-\mathrm{O}$ & Starch & Lammers et al., 2009 \\
\hline & 1130-1050, 1370 & - & Cellulose & Lammers et al., 2009 \\
\hline & 1072-1040 & $\mathrm{C}-\mathrm{O}$ & Cellulose, hemicellulose & Rico et al., 2015 \\
\hline & 1024-992 & - & Carbohydrate & Rico et al., 2015 \\
\hline & $928-912$ & - & Carbohydrate & Rico et al., 2015 \\
\hline
\end{tabular}

Changes in the regions of bands from radish sprouts were compared with data shown in this table.

\section{DISCUSSION}

\section{Seed Germination}

Nanoparticles tend to agglomerate in suspension due to their size, composition of the medium and ionic strength, among other variables (Murdock et al., 2008). nAg showed moderate agglomeration $(77 \pm 2.44 \mathrm{~nm})$ and negative surface charge when suspended in Millipore water (Murdock et al., 2008). However, these characteristics did not appear to interact with the cellulosic component of the radish seed coat (Esau, 1977). A previous study has shown that radish is a robust plant, in terms of germination under environmental stresses, due to the hard coat of it seeds that may prevent the entrance of contaminants, like heavy metals and nanoparticles (Koul et al., 2000). Previous studies have also shown no effects of heavy metal solutions or NP suspensions on radish germination. Lane and Martin (1977) reported no penetration of $\mathrm{Pb}$ within radish seeds exposed to $95 \mathrm{mg} / \mathrm{L}$ of "Analar," a lead nitrate solution. Lin and Xing (2007) reported that radish germination was not altered by $\mathrm{nAl}_{2} \mathrm{O}_{3}, \mathrm{nAl}, \mathrm{nZn}$, and $\mathrm{nZnO}$, even at the very high concentration of $2000 \mathrm{mg} / \mathrm{L}$. Wu et al. (2012) found that the $\mathrm{EC}_{50}$ for radish germination exposed to $\mathrm{nNiO}$ and $\mathrm{nCuO}$ was 401 and $398 \mathrm{mg} / \mathrm{L}$, respectively. TrujilloReyes et al. (2013) reported no effects on radish seed germination exposed up to $200 \mathrm{mg} / \mathrm{L}$ of citric acid coated and uncoated
$\mathrm{nCeO}_{2}$. Corral-Diaz et al. (2014) reported that germination of radish seeds sown in soil amended with $\mathrm{nCeO}_{2}$ at $0-500 \mathrm{mg} / \mathrm{kg}$ was retarded, but not reduced. Thus, it is not surprising that $\mathrm{nAg}$, even at $500 \mathrm{mg} / \mathrm{L}$, did not affect radish seed germination.

\section{Silver Uptake, Seedling Growth, Biomass Production, and Water Content}

The measurement of heavy metals or NPs' uptake by plant roots through ICP includes particles/elements adsorbed/ absorbed by the root system (Larue et al., 2012). Hong et al. (2015) showed that washing the tissues with $\mathrm{CaCl}_{2}$ and $\mathrm{HNO}_{3}$ removed about $80 \%$ of the $\mathrm{nCeO}_{2}$ sprayed to the leaves of cucumber. Thus, although radish seedlings were washed with $\mathrm{HNO}_{3}$ to remove the $\mathrm{nAg}$ adhered to the seedlings surface, some particles that could have remained were absorbed by the epidermis. Consequently, the reported data points include both the nAg adsorbed, plus the Ag taken up by the roots. The data reported in the present study, mainly at the highest concentration treatment $(500 \mathrm{mg} / \mathrm{L})$, differs from previously reported data. For instance, Song et al. (2013) reported no differences in silver uptake by tomato seedlings developed under exposure to 100 and $1000 \mathrm{mg} / \mathrm{L}$ of colloidal silver. These researchers determined that $\mathrm{nAg}$ hardly penetrated the hard coat of tomato seeds, and an analogous result could be expected with the hard coat of radish seeds (Koul et al., 

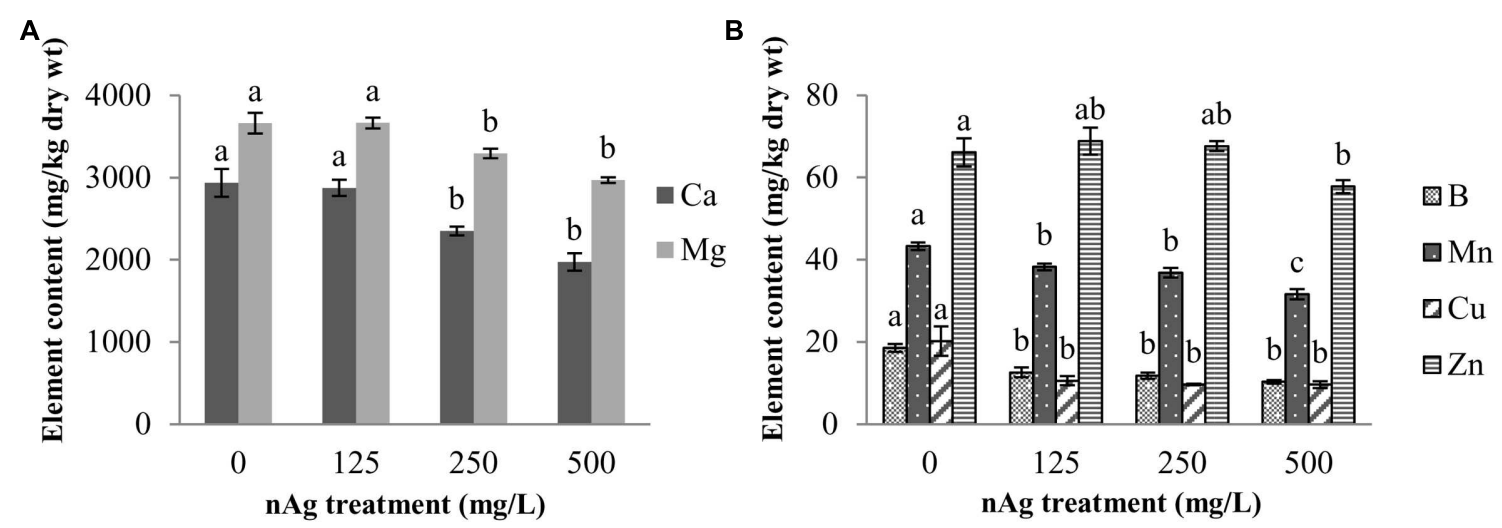

FIGURE 2 | Concentration of macroelements (A) and microelements (B) in radish seedlings germinated and grown for 5 days in $\mathrm{nAg}$ suspensions at 0 (control), 125, 250, and $\mathbf{5 0 0} \mathbf{~ m g / L}$. Values are means of four replicates per treatment (15 plants each) \pm standard error. Different letters denote statistically significant differences according to the Tukey's HSD test $(p<0.05)$.

C

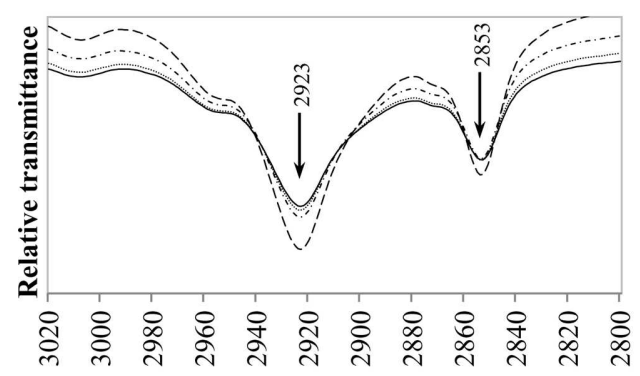

B

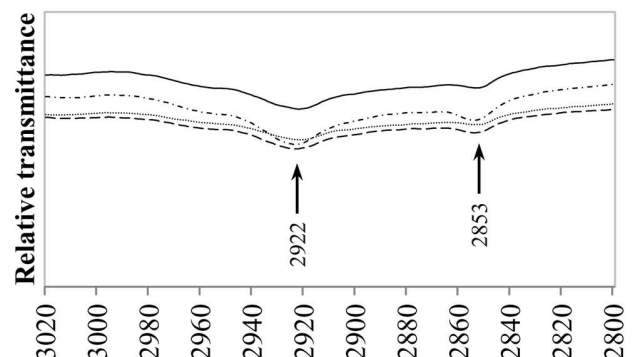

A

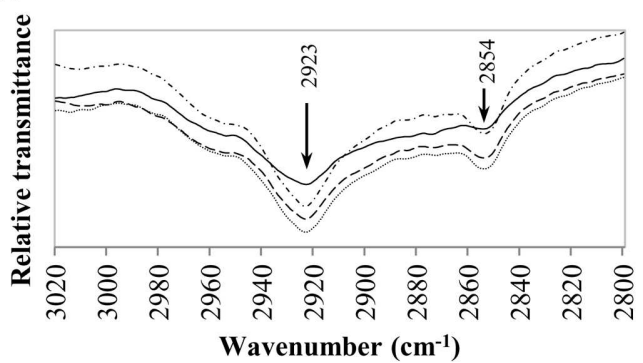

nAg $0 \mathrm{mg} / \mathrm{L} \quad \ldots \cdots \cdots \cdots \cdots \cdots \cdots \cdot \mathrm{nAg} 125 \mathrm{mg} / \mathrm{L}$
$\mathbf{F}$

Lipids, pectins

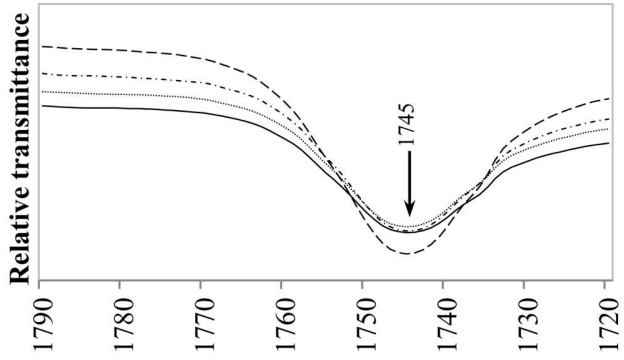

E

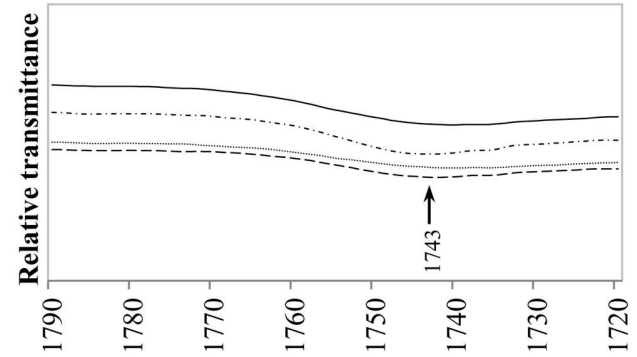

D

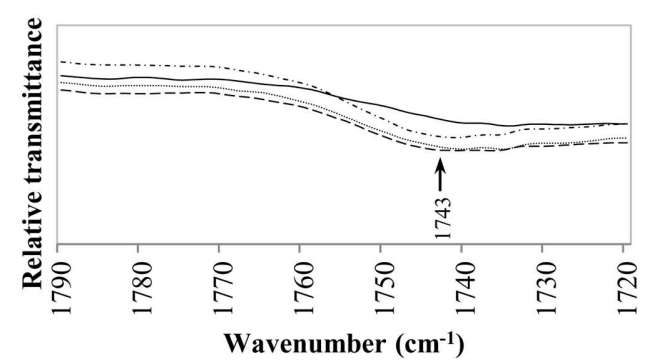

-..-nAg $250 \mathrm{mg} / \mathrm{L} \quad$ - - $\mathrm{nAg} 500 \mathrm{mg} / \mathrm{L}$

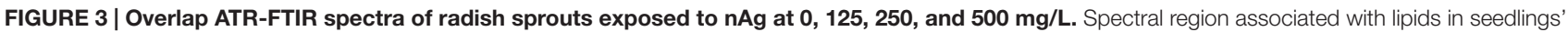
roots (A), stems (B) and leaves (C); and regions related to lipids and pectins in sprouts' roots (D), stems (E), and leaves (F). 

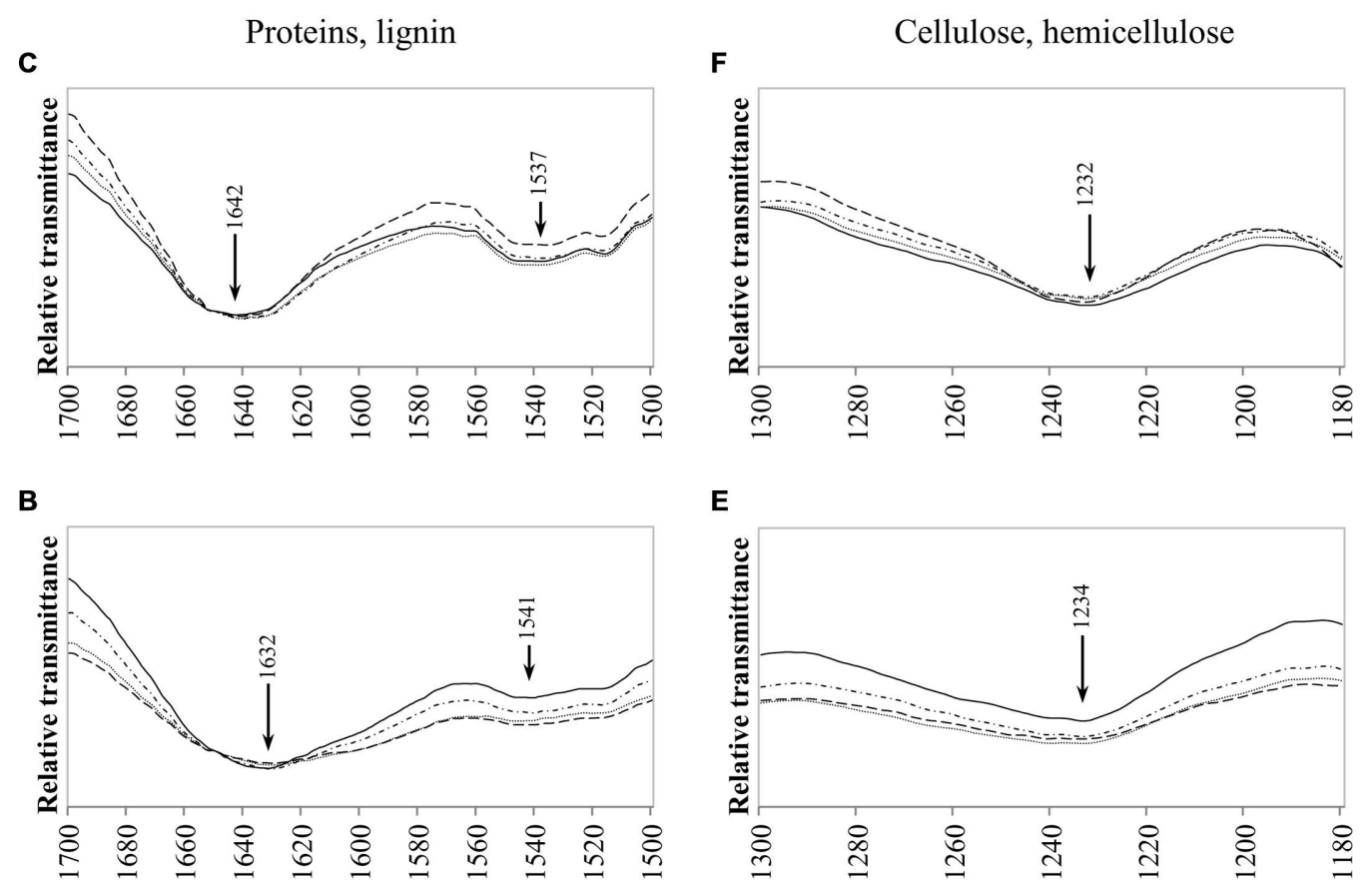

\section{E}
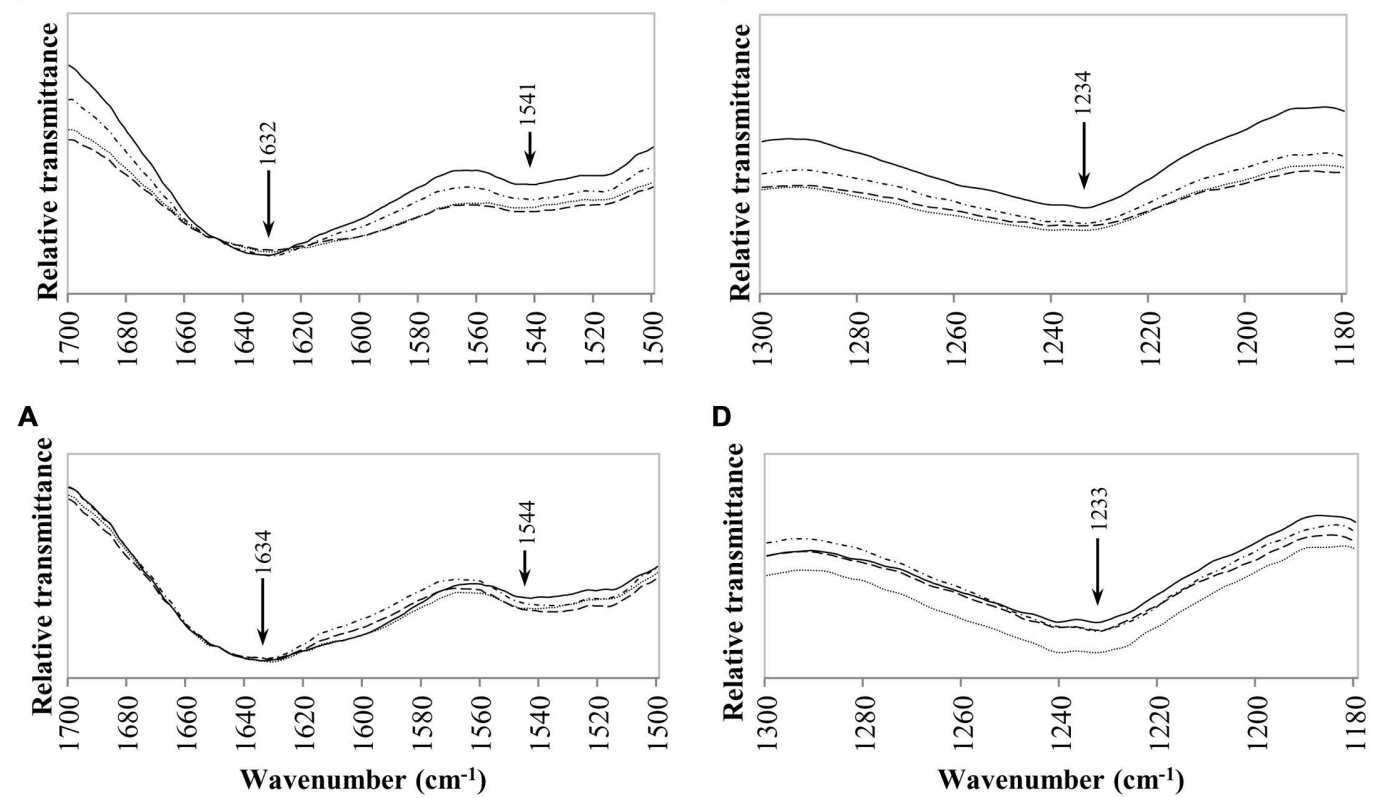

D

- nAg $0 \mathrm{mg} / \mathrm{L}$

……......nAg $125 \mathrm{mg} / \mathrm{L}$

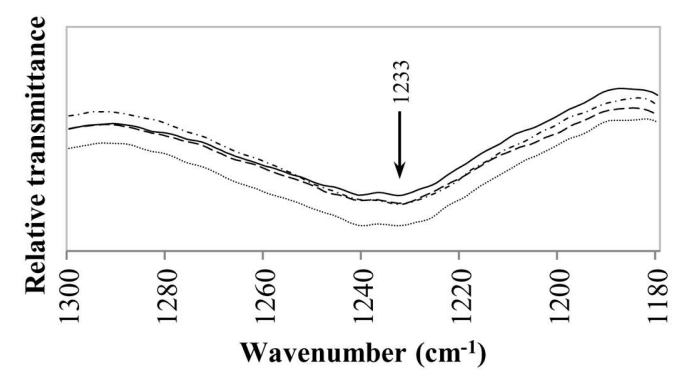

-... nAg $250 \mathrm{mg} / \mathrm{L} \quad$ - - $n$ nAg $500 \mathrm{mg} / \mathrm{L}$

FIGURE 4 | Overlap ATR-FTIR spectra of radish sprouts exposed to $\mathrm{nAg}$ at $\mathbf{0}, \mathbf{1 2 5}, \mathbf{2 5 0}$, and $\mathbf{5 0 0} \mathbf{m g} / \mathrm{L}$. Spectral region associated with proteins and lignin in seedlings' roots (A), stems (B), and leaves (C); and regions related to cellulose and hemicellulose in sprouts' roots (D), stems (E) and leaves (F).

2000). In specimens not protected by a hard coat, like rice seeds, penetration of the $\mathrm{nAg}$ has been associated with particle size and concentration. Thuesombat et al. (2014) soaked rice seedlings for $24 \mathrm{~h}$ in $1000 \mathrm{mg} / \mathrm{L}$ of either 20 or $150 \mathrm{~nm} \mathrm{nAg}$ and germinated the seeds in a sand bed. Seven days after germination, concentrations of $\mathrm{Ag}$ in roots were 22 and $12 \mathrm{mg} / \mathrm{kg}$, respectively. In our study, at $500 \mathrm{mg} / \mathrm{L}$ the uptake was higher than that reported by Thuesombat et al. (2014) at $1000 \mathrm{mg} / \mathrm{L}$; however, the particles used in the present study were of a smaller size, which could explain the difference. In addition, radish seedlings were in contact with the $\mathrm{nAg}$ suspension during the entire experimental period. Results from our study and reports from the literature indicate that the uptake of $\mathrm{Ag}$ from $\mathrm{nAg}$ depends on a series of factors such as treatment concentration, particle size, plant species, and exposure media.

There is no consistency in the reports of the effects of nAg on seedlings growth. For instance, Lee et al. (2012) reported a reduction of about $60 \%$ in mung bean and $75 \%$ in sorghum seedlings exposed in agar for 2 days to $\mathrm{nAg}$ at $10 \mathrm{mg} / \mathrm{L}$. These reduction rates are considerable larger than those observed in radish, although their support (agar) was different than the suspension used. However, the reduction in radish growth was similar to the reduction in sorghum, but different from that found with mung bean exposed in soil to $800 \mathrm{mg} / \mathrm{kg}$ of $\mathrm{nAg}$ (Lee et al., 2012), which does not support a comparison between liquid medium or agar. On the other hand, Nair and Chung (2014) exposed rice seedlings for 1 week to $\mathrm{nAg}$ in hydroponics (similar conditions of the present study), but at lower concentrations (0.2$1.0 \mathrm{mg} / \mathrm{L}$ ) and did not report changes in root elongation. This corroborates that the effects of $\mathrm{nAg}$ on root growth depend on a series of factors. In addition, differences in treatment concentrations and exposure media made it difficult to compare the results. 
C

\section{Carbohydrates}

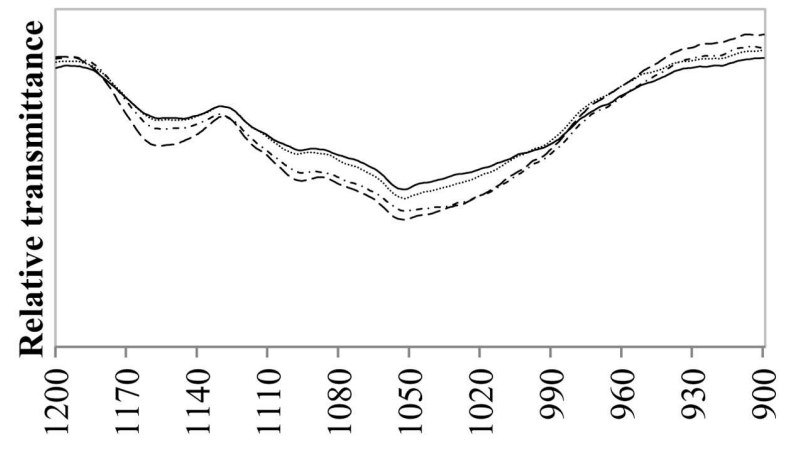

B

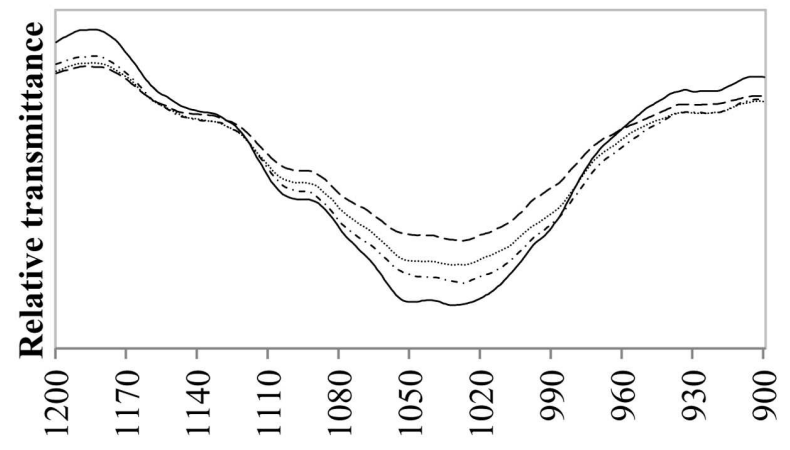

A

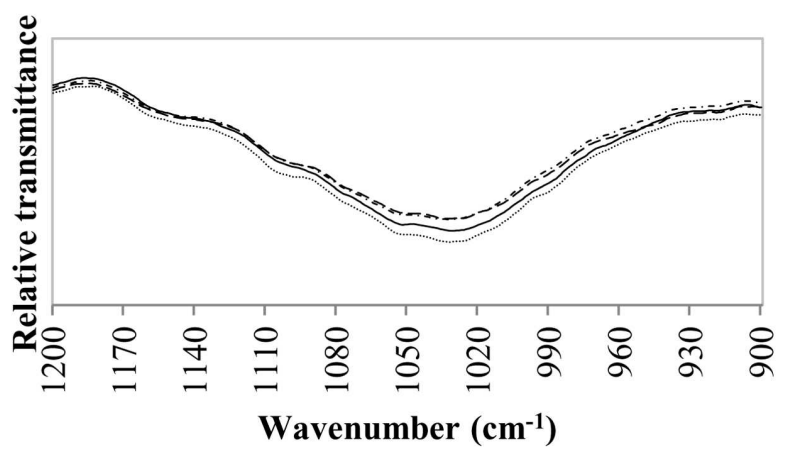

FIGURE 5 | Overlap ATR-FTIR spectra of radish sprouts exposed to

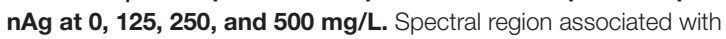
carbohydrates in seedlings' roots (A), stems (B), and leaves (C).
Our results on the effects of $\mathrm{nAg}$ in biomass production concurs with the reports found in 4-week old rice seedlings exposed to $\mathrm{nAg}$ at $0.1-1000 \mathrm{mg} / \mathrm{L}$ (Thuesombat et al., 2014). However, they differ from the results with tomato exposed for 15 days to a similar $\mathrm{nAg}$ concentration, where the reduction was about 75\% (Song et al., 2013). The mechanisms for reduction in biomass production by nAg are not known; however, Nair and
Chung (2014) found differential transcription of genes associated with stress tolerance, which could explain the reduction in biomass production.

The reduction in seedlings' water content under NP exposure has been previously reported. Trujillo-Reyes et al. (2014) found that $\mathrm{nCu}$ at 10 and $20 \mathrm{mg} / \mathrm{L}$ significantly reduced water content in lettuce. According to the literature, both $\mathrm{Cu}$ and $\mathrm{Ag}$ block water permeability in roots cells (Niemietz and Tyerman, 2002; Chang et al., 2012), which in turn reduce water absorption. In addition, Qian et al. (2013) proposed that $\mathrm{nAg}$ have the potential to change the transcription of antioxidant and aquaporin genes, affecting the balance of water in Arabidopsis. It is possible that nAg block aquaporins, reducing the water uptake in radish seedlings. This raises a question which requires more studies for a complete understanding of the aquaporins blockage by nAg.

\section{Effects of $n A g$ on Macro and Micronutrient Accumulation}

Previous studies have shown that the uptake of nutrient elements is affected by both the NM and the species of plant. For instance, Servin et al. (2013) reported increases in $\mathrm{Ca}, \mathrm{K}$, and $\mathrm{Mg}$ in cucumber exposed to $\mathrm{nTiO}_{2}$. TrujilloReyes et al. (2014) reported changes on the accumulation of $\mathrm{Mn}$ and $\mathrm{Zn}$ in lettuce leaves exposed to core-shell $\mathrm{Fe} / \mathrm{Fe}_{3} \mathrm{O}_{4}$ and $\mathrm{Cu} / \mathrm{CuO}$ NPs. Hong et al. (2015) exposed alfalfa and lettuce to several $\mathrm{Cu}$-based NPs/compounds in hydroponics and found changes in the absorption of some macroelements such as $\mathrm{K}, \mathrm{Mg}$, and $\mathrm{Cu}$. In addition, Trujillo-Reyes et al. (2013) reported tha $\mathrm{CeO}_{2}$ NPs modified the content of Mn and $\mathrm{Ni}$ in hydroponically grown radish. In the present study, it was found that $\mathrm{nAg}$ reduced the uptake of macroelements $\mathrm{Ca}$ and $\mathrm{Mg}$ and microelements like $\mathrm{B}, \mathrm{Mn}$, and $\mathrm{Zn}$. There is the possibility that $\mathrm{nAg}$ decrease the expression of the $\mathrm{Ca}$ channel protein, reducing Ca uptake. Magnesium is absorbed in a similar way as bacterial transporters CorA $\mathrm{Mg}^{2+}$ (Maathuis, 2009). It is very likely that at high concentrations, $\mathrm{nAg}$ are physically blocking the channels, reducing the absorption of Mg.

Boron uptake mechanisms include passive transport through the uncharged boric acid molecule, active transport through boron transporter 1 (BOR1) that uploads $\mathrm{B}$ into the xylem, and facilitated diffusion through channels belonging to intrinsic proteins (Dordas et al., 2000; Miwa and Fujiwara, 2010; Wimmer and Eichert, 2013). Trujillo-Reyes et al. (2013) reported that citric acid coated $\mathrm{nCeO}_{2}$ reduced the uptake of $\mathrm{B}$ in radish; however, to the best of the authors' knowledge, there is no explanation about the interference of NPs on B uptake. The uptake of Mn and Zn by roots is mediated by putative transporters, Nramp and ZIP family (Guerinot, 2000). The current information is not sufficient enough to get a clear idea of how nAg could affect the uptake of these microelements. As explained above, it is possible that $\mathrm{nAg}$ physically block the diffusion pathway or the channels for active absorption. In addition, Magesky and Pelletier (2015) mentioned that silver is a membrane disruptor that breaks down cellular homeostasis. Very likely, this disruption affected the uptake of 
essential elements. It is also possible that $\mathrm{nAg}$ down regulate the genes encoding for metal transporters. Further investigation is needed in order to unravel the mechanism of $\mathrm{nAg}$ interference with the uptake of micronutrients.

\section{FT-IR Functional Groups/Macromolecules Analysis}

According to Table 2, the $\mathrm{C}-\mathrm{H}$ bond in $\mathrm{CH}_{2}-\mathrm{CH}_{3}$ groups associated with lipids is found in the region of $3000-2800 \mathrm{~cm}^{-1}$. These macromolecules are constituents of the lipid bilayer found in cell membranes. Figures $\mathbf{3 A}-\mathbf{C}$ shows the relative transmittance of bands in the spectra obtained for roots, stems and leaves assigned to lipids in radish sprouts. Bands in the region between 1790 and $1720 \mathrm{~cm}^{-1}$ (Figures 3D-F) are associated to $\mathrm{C}=\mathrm{O}$ and $\mathrm{COOH}$ groups assigned also to lipids and pectins, these last are made of polysaccharides and are accountable for the structure of the primary cell wall.

Figures 4A-C shows the peaks found at $1650-1630 \mathrm{~cm}^{-1}$ for lignin and bonds identified for proteins at $1650 \mathrm{~cm}^{-1}, 1549$ $1530 \mathrm{~cm}^{-1}$ corresponding to $\mathrm{C}=\mathrm{O}, \mathrm{N}-\mathrm{H}$ and $\mathrm{C}-\mathrm{N}$ (Dokken and Davis, 2007; Rico et al., 2015). Changes in cellulose and hemicellulose are observed at $1242-1230$ and $1054-1051 \mathrm{~cm}^{-1}$ in Figures 4D-F and 5 respectively. Also, carbohydrates not attributed to a specific biopolymer are shown from 1200$900 \mathrm{~cm}^{-1}$ in Figure 5 .

Alterations in lipids and carbohydrates were similar to those reported for cilantro exposed to $\mathrm{nCeO}_{2}$ (Morales et al., 2013). While hemicellulose, cellulose and pectin are structural components of primary cell walls, lignin provides rigidity to terrestrial plants (Cabane et al., 2012). Disruption in these macromolecules may lead to changes in morphology that could impair the normal development of the plants. The fact that no band shifts were observed suggests that there are no chemical changes in the macromolecules studied, only shape alterations in the plant tissue components (Morales et al., 2013).

In summary, concentrations of $\mathrm{nAg}$ used in this study did not affect radish seed germination. However, there was a concentration-dependent reduction in seedling elongation and water content. In addition, at $250 \mathrm{mg} / \mathrm{L}$ the biomass was reduced by $10 \%$, compared with control $(p \leq 0.05)$. Silver NPs also impaired the absorption of nutritional elements in radish seedlings. Important macroelements such as $\mathrm{Ca}$ and $\mathrm{Mg}$ and microelements $\mathrm{B}, \mathrm{Cu}, \mathrm{Mn}$, and $\mathrm{Zn}$ were reduced by the highest

\section{REFERENCES}

Amooaghaie, R., Tabatabaei, F., and Ahadi, A. M. (2015). Role of hematin and sodium nitroprusside in regulating Brassica nigra seed germination under nanosilver and silver nitrate stresses. Ecotoxicol. Environ. Saf. 113, 259-270. doi: 10.1016/j.ecoenv.2014.12.017

Baenas, N., Ferreres, F., García-Viguera, C., and Moreno, D. A. (2015). Radish sprouts - characterization and elicitation of novel varieties rich in anthocyanins. Food Res. Int. 69, 305-312. doi: 10.1016/j.foodres.2015.0 1.009

Beer, C., Foldbjerg, R., Hayashi, Y., Sutherland, D. S., and Autrup, H. (2012). Toxicity of silver nanoparticles-nanoparticle or silver ion? Toxicol. Lett. 208, 286-292. doi: 10.1016/j.toxlet.2011.11.002 concentration of $\mathrm{nAg}$. Moreover, $\mathrm{nAg}$ induced conformational changes in carbohydrates, lignin, and lipids. The impacts of such changes in the nutritional value of radish sprouts are not known yet. In addition, as per Holden et al. (2014), "it may be premature for manufactured NMs risk research to sanction information on the basis of concentration 'environmental relevance'."

\section{AUTHOR CONTRIBUTIONS}

All authors listed, have made substantial, direct and intellectual contribution to the work, and approved it for publication.

\section{ACKNOWLEDGMENTS}

This material is based upon work supported by the National Science Foundation and the Environmental Protection Agency under Cooperative Agreement Number DBI-0830117. Any opinions, findings, and conclusions or recommendations expressed in this material are those of the author(s) and do not necessarily reflect the views of the National Science Foundation or the Environmental Protection Agency. This work has not been subjected to EPA review and no official endorsement should be inferred. The authors also acknowledge the USDA Grant number 2011-38422-30835 and the NSF Grant \# CHE0840525. Partial funding was provided by the NSF ERC on Nanotechnology-Enabled Water Treatment (EEC-1449500). This work was also supported by Grant 2G12MD007592 from the National Institutes on Minority Health and Health Disparities (NIMHD), a component of the National Institutes of Health (NIH). JG-T acknowledges the Dudley family for the Endowed Research Professorship and the Academy of Applied Science/US Army Research Office, Research and Engineering Apprenticeship program (REAP) at UTEP, grant \#W11NF-10-2-0076, subgrant 13-7. NZ-M acknowledges the "Consejo Nacional de Ciencia y Tecnología (CONACyT)" from Mexico and Dr. Jessica Trujillo-Reyes for her contribution in the experimental design.

\section{SUPPLEMENTARY MATERIAL}

The Supplementary Material for this article can be found online at: http://journal.frontiersin.org/article/10.3389/fpls.2016.00090

Cabane, M., Afif, D., and Hawkins, S. (2012). "Chapter 7: Lignins and abiotic stresses," in Advances in Botanical Research, eds J. Lise and L. Catherine (Cambridge, MA: Academic Press), 219-262.

Chang, Y.-N., Zhang, M., Xia, L., Zhang, J., and Xing, G. (2012). The toxic effects and mechanisms of $\mathrm{CuO}$ and $\mathrm{ZnO}$ nanoparticles. Materials 5, 2850-2871. doi: $10.3390 / \mathrm{ma} 5122850$

Corral-Diaz, B., Peralta-Videa, J. R., Alvarez-Parrilla, E., Rodrigo-García, J., Morales, M. I., Osuna-Avila, P., et al. (2014). Cerium oxide nanoparticles alter the antioxidant capacity but do not impact tuber ionome in Raphanus sativus (L). Plant Physiol. Biochem. 84, 277-285. doi: 10.1016/j.plaphy.2014.09.018

Daniel, S. C. G. K., Tharmaraj, V., Sironmani, T. A., and Pitchumani, K. (2010). Toxicity and immunological activity of silver nanoparticles. Appl. Clay Sci. 48, 547-551. doi: 10.1016/j.clay.2010.03.001 
de la Rosa, G., López-Moreno, M. L., Hernandez-Viezcas, J. A., Montes, M. O., Peralta-Videa, J., and Gardea-Torresdey, J. (2011). Toxicity and biotransformation of $\mathrm{ZnO}$ nanoparticles in the desert plants Prosopis julifloravelutina, Salsola tragus and Parkinsonia florida. Int. J. Nanotechnol. 8, 492-506. doi: 10.1504/IJNT.2011.040190

Dokken, K. M., and Davis, L. C. (2007). Infrared imaging of sunflower and maize root anatomy. J. Agric. Food Chem. 55, 10517-10530. doi: 10.1021/jf07 $2052 \mathrm{e}$

Dordas, C., Chrispeels, M. J., and Brown, P. H. (2000). Permeability and channelmediated transport of boric acid across membrane vesicles isolated from squash roots. Plant Physiol. 124, 1349-1362. doi: 10.1104/pp.124.3.1349

Esau, K. (1977). Anatomy of Seed Plants, 2nd Edn. Santa Barbara, CA: John Wiley, $455-473$.

Gardea-Torresdey, J. L., Rico, C. M., and White, J. C. (2014). Trophic transfer, transformation, and impact of engineered nanomaterials in terrestrial environments. Environ. Sci. Technol. 48, 2526-2540. doi: 10.1021/es4050665

Gottschalk, F., Sun, T. Y., and Nowack, B. (2013). Environmental concentrations of engineered nanomaterials: review of modeling and analytical studies. Environ. Pollut. 181, 287-300. doi: 10.1016/j.envpol.2013.06.003

Guerinot, M. L. (2000). The ZIP family of metal transporters. Biochim. Biophys. Acta 1465, 190-198. doi: 10.1016/S0005-2736(00)00138-3

Holden, P., Klaessig, F., Turco, R., Priester, J. H., Rico, C., Arias, H., et al. (2014). Evaluation of exposure concentrations used in assessing manufactured nanomaterial nnvironmental hazards: are they relevant? Environ. Sci. Technol. 48, 10541-10551. doi: 10.1021/es502440s

Hong, J., Rico, C. M., Zhao, L., Adeleye, A. S., Keller, A. A., Peralta-Videa, J. R., et al. (2015). Toxic effects of copper-based nanoparticles or compounds to lettuce (Lactuca sativa) and alfalfa (Medicago sativa). Environ. Sci. Process. Impacts 17, 177-185. doi: 10.1039/c4em00551a

Keller, A. A., Mcferran, S., Lazareva, A., and Suh, S. (2013). Global life cycle releases of engineered nanomaterials. J. Nanopart. Res. 15, 1-17. doi: 10.1007/s11051013-1692-4

Kim, J. S., Kuk, E., Yu, K. N., Kim, J. H., Park, S. J., Lee, H. J., et al. (2007). Antimicrobial effects of silver nanoparticles. Nanomedicine 3, 95-101. doi: 10.1016/j.nano.2006.12.001

Kostka-Rick, R., and Manning, W. J. (1993). Radish (Raphanus sativus L.): a model for studying plant responses to air pollutants and other environmental stresses. Environ. Pollut. 82, 107-138. doi: 10.1016/0269-7491(93)90109-2

Koul, K., Nagpal, R., and Raina, S. (2000). Seed coat microsculpturing in Brassica and allied genera (subtribes Brassicinae, Raphaninae, Moricandiinae). Ann. Bot. 86, 385-397. doi: 10.1006/anbo.2000.1197

Kumari, M., Mukherjee, A., and Chandrasekaran, N. (2009). Genotoxicity of silver nanoparticles in Allium cepa. Sci. Total Environ. 407, 5243-5246. doi: 10.1016/j.scitotenv.2009.06.024

Lammers, K., Arbuckle-Keil, G., and Dighton, J. (2009). FT-IR study of the changes in carbohydrate chemistry of three New Jersey pine barrens leaf litters during simulated control burning. Soil Biol. Biochem. 41, 340-347. doi: 10.1016/j.soilbio.2008.11.005

Lane, S., and Martin, E. (1977). A histochemical investigation of lead uptake in Raphanus sativus. New Phytol. 79, 281-286. doi: 10.1111/j.14698137.1977.tb02206.x

Larue, C., Laurette, J., Herlin-Boime, N., Khodja, H., Fayard, B., Flank, A. M., et al. (2012). Accumulation, translocation and impact of $\mathrm{TiO} 2$ nanoparticles in wheat (Triticum aestivum spp.): influence of diameter and crystal phase. Sci. Total Environ. 431, 197-208. doi: 10.1016/j.scitotenv.2012.04.073

Lee, W. M., Kwak, J. I., and An, Y. J. (2012). Effect of silver nanoparticles in crop plants Phaseolus radiatus and Sorghum bicolor: media effect on phytotoxicity. Chemosphere 86, 491-499. doi: 10.1016/j.chemosphere.2011. 10.013

Létondor, C., Pascal-Lorber, S., and Laurent, F. (2015). Uptake and distribution of chlordecone in radish: different contamination routes in edible roots. Chemosphere 118, 20-28. doi: 10.1016/j.chemosphere.2014.03.102

Lin, D., and Xing, B. (2007). Phytotoxicity of nanoparticles: inhibition of seed germination and root growth. Environ. Pollut. 150, 243-250. doi: 10.1016/j.envpol.2007.01.016

López-Moreno, M. L., De La Rosa, G., Hernández-Viezcas, J. A., Peralta-Videa, J. R., and Gardea-Torresdey, J. L. (2010). X-ray absorption spectroscopy (XAS) corroboration of the uptake and storage of $\mathrm{CeO}_{2}$ nanoparticles and assessment of their differential toxicity in four edible plant species. J. Agric. Food Chem. 58, 3689-3693. doi: 10.1021/jf904472e

Ma, Y., Kuang, L., He, X., Bai, W., Ding, Y., Zhang, Z., et al. (2010). Effects of rare earth oxide nanoparticles on root elongation of plants. Chemosphere 78, 273-279. doi: 10.1016/j.chemosphere.2009.10.050

Maathuis, F. J. M. (2009). Physiological functions of mineral macronutrients. Curr. Opin. Plant Biol. 12, 250-258. doi: 10.1016/j.pbi.2009. 04.003

Magesky, A., and Pelletier, E. (2015). Toxicity mechanisms of ionic silver and polymer-coated silver nanoparticles with interactions of functionalized carbon nanotubes on early development stages of sea urchin. Aquat. Toxicol. 167, 106-123. doi: 10.1016/j.aquatox.2015.07.011

Miwa, K., and Fujiwara, T. (2010). Boron transport in plants: co-ordinated regulation of transporters. Ann. Bot. 105, 1103-1108. doi: 10.1093/aob/ mcq044

Morales, M. I., Rico, C. M., Hernandez-Viezcas, J. A., Nunez, J. E., Barrios, A. C., Tafoya, A., et al. (2013). Toxicity assessment of cerium oxide nanoparticles in cilantro (Coriandrum sativum L.) plants grown in organic soil. J. Agric. Food Chem. 61, 6224-6230. doi: 10.1021/jf401628v

Murdock, R. C., Bradich-Stolle, L., Schrand, A. M., Schlanger, J. J., and Hussain, S. M. (2008). Characterization of nanomaterial dispersion in solution prior to in vitro exposure using dynamic light scaterring technique. Toxicol. Sci. 101, 239-253. doi: 10.1093/toxsci/ $/ \mathrm{kfm} 240$

Musante, C., and White, J. C. (2012). Toxicity of silver and copper to Cucurbita pepo: differential effects of nano and bulk-size particles. Environ. Toxicol. 27, 510-517. doi: 10.1002/tox.20667

Nair, P. M. G., and Chung, I. M. (2014). Physiological and molecular level effects of silver nanoparticles exposure in rice (Oryza sativa L.) seedlings. Chemosphere 112, 105-113. doi: 10.1016/j.chemosphere.2014.03.056

Niemietz, C. M., and Tyerman, S. D. (2002). New potent inhibitors of aquaporins: silver and gold compounds inhibit aquaporins of plant and human origin. FEBS Lett. 531, 443-447. doi: 10.1016/S0014-5793(02)03 581-0

Pokhrel, L. R., and Dubey, B. (2013). Evaluation of developmental responses of two crop plants exposed to silver and zinc oxide nanoparticles. Sci. Total Environ. 45, 321-332. doi: 10.1016/j.scitotenv.2013.02.059

Qian, H., Peng, X., Han, X., Ren, J., Sun, L., and Fu, Z. (2013). Comparison of the toxicity of silver nanoparticles and silver ions on the growth of terrestrial plant model Arabidopsis thaliana. J. Environ. Sci. 25, 1947-1956. doi: 10.1016/S10010742(12)60301-5

Rico, C. M., Peralta-Videa, J. R., and Gardea-Torresdey, J. L. (2015). Differential effects of cerium oxide nanoparticles on rice, wheat, and barley roots: a fourier transform infrared (FT-IR) microspectroscopy study. Appl. Spectrosc. 69, 287-295. doi: 10.1366/14-07495

Roco, M. C. (2003). Nanotechnology: convergence with modern biology and medicine. Curr. Opin. Biotechnol. 14, 337-346. doi: 10.1016/S09581669(03)00068-5

Servin, A. D., Morales, M. I., Castillo-Michel, H., Hernandez-Viezcas, J. A., Munoz, B., Zhao, L., et al. (2013). Synchrotron verification of $\mathrm{TiO} 2$ accumulation in cucumber fruit: a possible pathway of $\mathrm{TiO} 2$ nanoparticle transfer from soil into the food chain. Environ. Sci. Technol. 47, 11592-11598. doi: $10.1021 /$ es403368j

Song, U., Jun, H., Waldman, B., Roh, J., Kim, Y., Yi, J., et al. (2013). Functional analyses of nanoparticle toxicity: a comparative study of the effects of $\mathrm{TiO} 2$ and Ag on tomatoes (Lycopersicon esculentum). Ecotoxicol. Environ. Saf. 93, 60-67. doi: 10.1016/j.ecoenv.2013.03.033

Stampoulis, D., Sinha, S. K., and White, J. C. (2009). Assay-dependent phytotoxicity of nanoparticles to plants. Environ. Sci. Technol. 43, 9473-9479. doi: $10.1021 /$ es $901695 \mathrm{c}$

Thuesombat, P., Hannongbua, S., Akasit, S., and Chadchawan, S. (2014). Effect of silver nanoparticles on rice (Oryza sativa L. $c v$. KDML 105) seed germination and seedling growth. Ecotoxicol. Environ. Saf. 104, 302-309. doi: 10.1016/j.ecoenv.2014.03.022

Trujillo-Reyes, J., Majumdar, S., Botez, C. E., Peralta-Videa, J. R., and GardeaTorresdey, J. L. (2014). Exposure studies of core-shell $\mathrm{Fe} / \mathrm{Fe} 3 \mathrm{O} 4$ and $\mathrm{Cu} / \mathrm{CuO} \mathrm{NPs}$ to lettuce (Lactuca sativa) plants: are they a potential physiological and nutritional hazard? J. Hazard. Mater. 267, 255-263. doi: 10.1016/j.jhazmat.2013.11.067 
Trujillo-Reyes, J., Vilchis-Nestor, A., Majumdar, S., Peralta-Videa, J., and Gardea-Torresdey, J. (2013). Citric acid modifies surface properties of commercial $\mathrm{CeO}_{2}$ nanoparticles reducing their toxicity and cerium uptake in radish (Raphanus sativus) seedlings. J. Hazard. Mater. 263, 677-684. doi: 10.1016/j.jhazmat.2013.10.030

Wimmer, M. A., and Eichert, T. (2013). Review: mechanisms for boron deficiency-mediated changes in plant water relations. Plant Sci. 20, 25-32. doi: 10.1016/j.plantsci.2012.12.012

Wu, S. G., Huang, L., Head, J., Chen, D. R., Kong, I. C., and Tang, Y. J. (2012). Phytotoxicity of metal oxide nanoparticles is related to both dissolved metals ions and adsorption of particles on seed surfaces. J. Pet. Environ. Biotechnol. 3, 1-5. doi: 10.4172/2157-7463.1000126

Xiao, Z., Luo, Y., Lester, G. E., Kou, L., Yang, T., and Wang, Q. (2014). Postharvest quality and shelf life of radish microgreens as impacted by storage temperature, packaging film, and chlorine wash treatment. LWT-Food Sci. Technol. 55, 551-558. doi: 10.1016/j.lwt.2013.09.009

Yin, L., Colman, B. P., McGill, B. M., Wright, J. P., and Bernhardt, E. S. (2012). Exposure of silver nanoaprticloe exposure on germination and early growth of eleven wetland plants. PLoS ONE 7:e47674. doi: 10.1371/journal.pone.004 7674

Yu, C., and Irudayaraj, J. (2005). Spectroscopic characterization of microorganisms by Fourier transform infrared microspectroscopy. Biopolymers 77, 368-377. doi: 10.1002/bip.20247

Conflict of Interest Statement: The authors declare that the research was conducted in the absence of any commercial or financial relationships that could be construed as a potential conflict of interest.

Copyright (c) 2016 Zuverza-Mena, Armendariz, Peralta-Videa and GardeaTorresdey. This is an open-access article distributed under the terms of the Creative Commons Attribution License (CC BY). The use, distribution or reproduction in other forums is permitted, provided the original author(s) or licensor are credited and that the original publication in this journal is cited, in accordance with accepted academic practice. No use, distribution or reproduction is permitted which does not comply with these terms. 